\title{
MULHERES ENTRE - VISTAS: UM CONVERSARE INTERGERACIONAL
}

\section{INTER-VIEWS WOMEN: AN INTERGENERATIONAL CONVERSATION}

\author{
Maria Alice Costa \\ Naiara Coelho* \\ Monique Rodrigues Lopes ${ }^{* \star}$ \\ Maria Alzira de Oliveira Noli
}

Resumo: Este artigo tem como objetivo analisar o feminismo, a partir da história de vida de quatro mulheres nascidas em três diferentes décadas (1930, 1960 e 1990); e, com distintas percepções sobre o que é ser mulher e o feminismo. Essas mulheres entrevistadas são as autoras deste artigo. Partimos da metodologia de entrevista estruturada e da história de vida como fonte de resgate e registro da memória das experiências dessas mulheres. Nesse sentido, este artigo poderá vir a colaborar na interlocução intergeracional e em análises comparativas de diferentes posicionamentos geracionais. Estaremos focadas nos relatos e percepções pessoais sobre o feminismo; o poder hegemônico masculino; e, sobre o ser, viver e sentir-se mulher num mundo machista. Esta entre-vista permitirá o compartilhamento das narrativas culturais dessas mulheres e seus pontos de vistas. Encontrar um denominador comum sobre o que é o feminismo entre as três diferentes gerações contidas neste artigo, será o desafio de nossa análise realizada através da interseção e da triangulação dos diálogos construídos organicamente entre elas.

Palavras-Chave: Feminismo. Mulheres. Entrevista intergeracional. Machismo. Memórias.

Abstract: This article aims to analyze feminism, from the life history of four women born in three different decades (1930, 1960 and 1990); and with different perceptions about what it is to be a woman and feminism. These women interviewed are the authors of this article. We start from the methodology of structured interview and the history of life as a source of rescue and record of the memory of the experiences of

\footnotetext{
Maria Alice Costa é cientista social (UFF), mestra em Ciência Política (UFF), doutora em Planejamento Urbano (UFRJ/IPPUR) e pós-doutorado em Sociologia (CES/Universidade de Coimbra). Ela é orientadora de Monique Lopes e Naiara Coelho em suas dissertações de Mestrado sobre o Feminismo, no Programa de Pós-Graduação em Sociologia e Direito da Universidade Federal Fluminense (PPGSD/UFF).

Naiara Coelho é bacharela em Direito pela Pontifícia Universidade Católica do Paraná (Campus Maringá), advogada, membra do Instituto de Mulheres Negras Enedina Alves Marques e exconselheira do Conselho da Mulher de Maringá-PR, pelo mesmo Instituto.

Monique Lopes é historiadora pela Universidade Federal de Viçosa-MG e graduanda em Direito pela Universidade Estácio de Sá (Niterói).

Maria Alzira de Oliveira Noli é professora de geografia aposentada. Agradecemos imensamente o aceite de Maria Alzira Noli para participar desta entrevista/conversa, na medida em que sua participação representa uma outra geração que enriquece, sobremaneira, este artigo.
} 
these women. In this sense, this article may collaborate in intergenerational interlocution and in comparative analyzes of different generational positions. We will be focused on personal accounts and perceptions about feminism; male hegemonic power; and about being, living and feeling like a woman in a sexist world. This interview will allow the sharing of the cultural narratives of these women and their points of view. Finding a common denominator about feminism among the three different generations in this article will be the challenge of our analysis through the intersection and triangulation of the dialogues constructed organically between them.

Keywords: Feminism. Women. Intergenerational Interview. Chauvinism. Memoirs. 


\section{INTRODUÇÃO}

Este artigo tem como objetivo registrar a história de vida de quatro mulheres vividas em três diferentes décadas do século XX (1930, 1960 e 1990); nesse sentido, com diferentes percepções sobre o que é ser mulher e o feminismo. Partimos da metodologia de uma entrevista estruturada, a partir do diálogo e a interseção da história de vida dessas mulheres que estarão pensando e repensando a produção dos sentidos que possuem sobre o ser mulher, em suas diferentes gerações e dimensões. Acreditamos que o registro de suas vidas, possa vir a colaborar na interlocução intergeracional e, em análises comparativas sobre a maneira como diferentes gerações percebem o feminismo; o poder masculino; e, sobre o ser, viver e sentir-se mulher num mundo estruturalmente machista.

Para alguns historiadores mais tradicionais, a memória não é digna de crédito como fonte histórica, na medida em que a memória pode ser distorcida e influenciada por versões coletivas. Segundo Jacques Le Goff (1992), este não é um problema metodológico. Para o autor, a memória é uma construção psíquica e intelectual que acarreta de fato uma representação seletiva do passado, que nem sempre é somente aquela do indivíduo. A memória representa um coletivo de memórias de pessoas inseridas em determinados contextos familiares, sociais, culturais e econômicos. Desta forma, recordar representa a rememoração de acontecimentos, situações e de pessoas situadas em outros tempos e lugares. Porém, é o tempo presente nas entrevistas que serve de ponto de partida para a rememoração. Voltar no tempo é um exercício que necessita de um constante ir e voltar, pois, cada lembrança ancora-se a um momento do presente.

Para Halbwachs (1990), a lembrança é uma reconstrução do passado com a ajuda de dados emprestados do presente e reconstruções do passado. Nesse sentido, este artigo parte do pressuposto que é preciso reconhecer as memórias individuais das mulheres, entrevistadas neste artigo, que são construídas a partir de vivências que elas experimentaram no curso de suas vidas, no interior de seus grupos sociais. Essas vivências não são únicas. Elas representam lembranças e 
vivências coletivas de muitas outras mulheres de seu tempo e, de cada grupo e classe social à qual pertencem.

Portanto, este artigo reconhece que entrevistar é estabelecer uma relação comunicativa. Buscaremos as singularidades de suas trajetórias pessoais e da visão de mundo de cada colaboradora. Estaremos conversando. Conversare significa se virar junto para alguém ou virar sua atenção para outra pessoa. Isso remete-nos o sentido de liberdade de expressão e democracia: reconhecer e respeitar o pensamento de cada pessoa.

Desta forma, pretendemos propiciar a materialidade de um diálogo intergeracional com diversas percepções, que possa vir a contribuir para a expansão de diálogos democráticos entre mulheres de diferentes etapas e experiências de vida. Neste artigo, a entrevista acontece entre quatro mulheres: duas jovens nascidas na década de noventa (Naiara e Monique); uma de meia idade nascida nos anos sessenta (Maria Alice); e, a outra da terceira idade, nascida na década de trinta (Maria Alzira). Naiara e Monique são mestrandas do Programa de Pós-Graduação em Sociologia e Direito da Universidade Federal Fluminense. Naiara, feminista e paranaense, tem 25 anos, é nascida e criada em Maringá e se identifica como negra de pele clara, por compreender que, no Brasil, questões raciais são permeadas pelo "colorismo"'. Ela, como mestranda, pesquisa a participação das mulheres na política, pela ótica das Teorias Feministas.

Monique é feminista, tem 28 anos, mineira da cidade Rio Pomba, e se considera parda e também defende os pressupostos do colorismo. Hoje, como mestranda, pesquisa políticas públicas na construção de direitos para mulheres. Maria Alice tem 55 anos, carioca e considera-se branca, neta de bisavó alemã e neta de avó austríaca. Mas, tem grande identificação com a herança indígena, e é professora há 42 anos. Maria Alzira de Oliveira Noli é branca e tem 88 anos. Ela é

\footnotetext{
${ }^{1} \mathrm{O}$ colorismo destaca um tipo de discriminação que é baseada no fenótipo das pessoas, ou seja, quanto mais características negroides, maior o preconceito; e, quanto mais características brancas/europeias, menor a discriminação. Segundo Margareth Hunter (2007), as pessoas de pele mais clara desfrutam de privilégios substanciais que ainda são inatingíveis aos seus irmãos e irmãs de pele mais escura. Desta forma, a história tem nos mostrado que pessoas de pele clara ganham mais dinheiro, frequentam por mais tempo a escola, vivem em bairros melhores e casam-se com pessoas de maior status social, do que pessoas de pele mais escura, da mesma raça ou etnia. Para saber mais sobre o colorismo ver: HUNTER (2007).
} 
geógrafa, especialista em Política Internacional e foi professora de História e Geografia por 30 anos. Ela adora fazer festas com a família, vai ao teatro, viaja, frequenta cursos de inglês e piano, assiste a filmes, encontra-se com as amigas, discute política, adora beber vinho, comer chocolate e, vive intensamente.

Essa diversidade etária de nossas autoras e entrevistadas é de suma importância para o reconhecimento geracional das mulheres. A trajetória histórica feminista contou, majoritariamente, com o movimento de mulheres jovens. Contudo, observamos que as reivindicações "feministas" se reinventam no tempo, ainda que estejam longe de se concretizarem em sua plenitude. A socióloga Dulce Whitaker (2007), nos alerta sobre culturas que supervalorizam a juventude e acabam por produzir a perda do poder de pessoas mais velhas. Em seu trabalho, a autora contribui para desestigmatizar a velhice, principalmente no Brasil, nos mostrando que as mulheres idosas não estão, hoje, somente sentadas no sofá vendo a vida passar. Elas estão ativas, reveem posições, reformulam atitudes e reparam erros; na medida em que estão em constante trabalho de memória. Portanto, as mulheres idosas precisam também ser reconhecidas pelo universo jovem feminino. As mulheres mais velhas também precisam ser desestigmatizadas e ouvidas, ocupando os espaços públicos com respeito e dignidade.

$\mathrm{Na}$ trajetória histórica do movimento feminista, podemos visualizar - ainda que não haja um consenso generalizado - três dimensões ou ondas ${ }^{2}$ distintas do feminismo no contexto internacional. A primeira onda foi impulsionada a partir do movimento sufragista do século XIX até o final da II Guerra Mundial, época onde pode-se observar o significativo papel desempenhado pelas mulheres na economia, enquanto os homens foram para a guerra. A segunda onda feminista emergiu a partir dos movimentos feministas nos EUA e Europa da década de 60, gerando debates mais globais. A terceira onda tem sido tradicionalmente considerada a partir do Ano Internacional das Mulheres em 1975 e da "Década da ONU para as Mulheres". Segundo Céli Pinto (2003), essas três ondas explicadas de maneira

\footnotetext{
${ }^{2}$ Utilizamos as categorias "ondas" e "dimensões" nesse artigo. Contudo, entendemos como mais adequado o uso do conceito "dimensão". Acreditamos que, a importação de categorias coloniais para a explicação de fenômenos ocorridos na América Latina, não consegue abarcar as especificidades e nuances próprias desses locais; e, por isso, exigem categorias próprias. Para saber mais sobre o uso do termo "onda" e "dimensão" ver: ALVAREZ (2003).
} 
genérica, buscam evidenciar momentos de mudanças substanciais na sociedade, cada uma delas com reivindicações e estratégias específicas.

Nas primeiras décadas do século $\mathrm{XX}$, a onda feminista foi marcada pela luta do direito ao voto e profissionalização das mulheres, baseando-se numa vertente feminista liberal ou do feminismo da igualdade. A principal estratégia das mulheres dessa época era afirmar que homens e mulheres são iguais e, por isso, deveriam ter as mesmas oportunidades, sem críticas diretas à estrutura de dominação. Fundamentadas pelo pensamento liberal e embasadas em questões como a autonomia individual, ficaram conhecidas como sufragistas, dada a luta e conquista do direito ao voto. Apesar da ausência de crítica com relação à estrutura patriarcal, a luta dessas mulheres constituiu um passo importante para a conquista formal de direitos civis e políticos. As mulheres que compunham essa primeira onda eram, em sua grande maioria, brancas de classe alta e escolarizadas, o que representava um número bastante restrito da sociedade brasileira.

A segunda onda, a partir da década de 1960, teve uma abertura significativa para os movimentos populares, mulheres trabalhadoras e de classe mais baixa, mudando, portanto, de forma significativa o perfil dos grupos feministas e de mulheres que lutavam por seus direitos. Elas eram acadêmicas, militantes políticas, sindicalistas e donas-de-casa que tiveram suas/seus filhas/filhos e maridos perseguidos, presos ou mortos em guerras e, em países que viviam em uma ditadura. Nesse período, prevaleceu o chamado feminismo da diferença, por meio do qual as mulheres apontavam justamente o que as diferenciava dos homens para legitimar suas demandas. Dada a sua base popular, uma das vertentes feministas de destaque nesse período, foi o feminismo marxista, que inclui a análise da exploração do proletariado e a opressão que as mulheres sofriam. Nesse momento, com o advento da criação da pílula anticoncepcional e da revolução sexual, abre-se a discussão sobre sexualidade, liberdade sexual e de um maior controle sobre a maternidade.

Em 1985, no Fórum de ONGs (organizações não governamentais) que marcou o fim da "Década das Nações Unidas para as Mulheres", foi lançada uma das redes feministas mais influentes nas duas décadas seguintes: Development 
Alternatives with Women for a New Era (DAWN). O processo de construção de redes feministas esteve em evidência na década de 90 , período marcado pelo entusiasmo em torno de redes transnacionais com organizações internacionais, conferências organizadas pela ONU sobre diversos temas, norteados pela crença da importância da valorização dos direitos humanos e do desenvolvimento. Diversas organizações e movimentos da sociedade civil participaram amplamente desse processo por meio de redes nacionais e internacionais, em expansão nos dias atuais.

Esta terceira onda no Brasil, na década de 90, foi marcada de forma mais emblemática pela entrada do poder de mulheres em instituições governamentais, bem como na criação de órgãos específicos para a proteção dos seus direitos, como as Secretarias, Conselhos, Delegacias da Mulher, dentre outras políticas públicas para as mulheres. Nesse período, em particular no mundo acadêmico, passaram a ser discutidas questões como o lesbianismo, a especificidade da opressão que sofrem as mulheres negras e indígenas - através do feminismo de matriz africana e indígena. No Brasil, as mulheres também conquistaram em 1995, a Lei Federal 9.100/95, que determina cotas para a candidatura de mulheres em cada partido ou coligação eleitoral.

Atualmente, algumas autoras tais como, Alvarez (2003); Matos (2010); e, Fraser (2015), chegam a falar que vivemos a "quarta onda feminista". Conforme Marlise Matos (2010), vivemos o "feminismo de rede", onde pautas e reivindicações das mulheres se expandiram e se interconectaram por redes sociais, tanto a partir de movimento de militância feminista, quanto por coletivos de mulheres feministas, de mulheres de organizações governamentais, parlamentares, cientistas, dentre outros movimentos da internet, que formam redes de debate, análises e de reivindicações feministas.

A seguir, iremos ao diálogo entre essas quatro mulheres de diferentes gerações, cores e saberes, acreditando que a polissemia interpretativa pode nos ajudar a admirar. Aqui, ressaltamos que não basta tolerar o pensamento e as ideias da outra. Tolerar é apenas aturar a outra como estranha ou exótica. Nesse sentido, o termo carrega, implicitamente, uma postura e uma concepção de estranhamento e, até mesmo, de violência simbólica. Tolerar nos distancia. Olhar junto é diferente, 
porque nos aproxima. Capacita-nos a traduzir e compreender as suas experiências e, consequentemente, a ampliar e trocar saberes. Admirar, etimologicamente, significa olhar/mirar junto. Admirar é exercitar o olhar da estética e da ética da alteridade. Ver e olhar à luz do fluxo constante e dinâmico do mundo, deriva da percepção da nossa interdependência existencial.

\section{CONCEPÇÕES SOBRE O FEMINISMO}

MARIA ALICE - Em que momento da vida, vocês começaram a pensar em Feminismo? E como foi essa trajetória, como mulheres, até resolverem fazer uma Dissertação de Mestrado sobre o Feminismo?

Monique: Sempre almejei por buscar formas mais justas de relações sociais, que prezassem pela dignidade humana e que me fizessem compreender a trajetória da humanidade. Por isso me formei historiadora e, no curso, tive contato com o feminismo. Como define Chimamanda Ngozi Adichie (2014, p. 17), "feminista é uma pessoa que acredita na igualdade social, política e econômica entre os sexos". Dessa forma, se fez necessário - para mim - também escrever sobre o feminismo numa perspectiva acadêmica, por ser uma questão que me atravessa das mais diversas formas.

Naiara: Pensar o feminismo academicamente é mais recente pra mim. Começou enquanto eu cursava Direito e, mais intensamente, quando passei a estagiar numa Vara de Violência Doméstica. Porém, entendo que o feminismo está para além dos estudos. Sinto que perceber o mundo como desigual entre homens e mulheres fez parte da minha trajetória de vida, independente da academia. Minha mãe, além de compor grupos sociais de mulheres, sempre foi um exemplo dessa desigualdade e inspiração para eu pensar e lutar por mudanças. Por isso, essa temática tem uma extrema importância, que a levei para a minha vida pessoal, profissional e acadêmica. Durante a graduação, fiz algumas pesquisas sobre temas afins (como a pornografia de revanche e a regulamentação da prostituição). Posteriormente, comecei a atuar no Conselho Municipal da Mulher de Maringá-PR e, pude perceber, o quanto a falta de mulheres no ambiente político limita a possibilidade de 
criar/efetivar políticas públicas a nós mulheres. Ter vivenciado o impeachment da primeira presidenta do Brasil - observando vários aspectos sexistas, durante o processo; bem como acompanhar a eleição de 2016 do município de Maringá, quando, ao longo de 28 anos, nenhuma mulher havia sido eleita. Então resolvi, me debruçar a pensar sobre a participação e representação das mulheres na política, durante o mestrado.

NAIARA - Quando foi que o feminismo passou a ser parte da sua vida? Vocês se lembram de uma pessoa ou situação específica em que o feminismo se introduziu em suas vivências? Como foi isso?

Maria Alzira - Foi quando, adolescente, li a biografia de Marie Curie - a grande física que estudou a radiatividade e primeira mulher a receber um prêmio Nobel. Ela era polonesa, naturalizada francesa. Ainda na Polônia, foi impedida de frequentar um curso superior, devido ao "CRIME" de ser mulher. A partir dessa época, comecei a observar como a mulher era discriminada. Escritoras escreviam com pseudônimo masculino para poderem ter seus manuscritos lidos por editores. Havia carreiras que não eram "próprias" para mulheres. E assim, fui vendo que só pelo fato de ser mulher, a pessoa já levava muita desvantagem no decorrer de sua vida. Desta forma, tomei conhecimento sobre o feminismo a partir do conhecimento desta situação da mulher. Na vida sempre se muda. Viver é isto, seguir em frente, mas nem sempre em linha reta. Mas, essencialmente, achava, e ainda acho, que homens e mulheres têm que ter a mesma oportunidade na vida. Não acho que se deva dar mais chance a um ou a outro.

Maria Alice - Meu ativismo feminista se situa na esfera micropolítica do meu poder como filha, irmã, mãe, avó, prima, vizinha, amiga, companheira, citadina, cientista social, professora, fotógrafa e mulher. Sou uma humanista que luta pelos direitos e pelo respeito entre todos os seres humanos. Essa é a minha luta diária, no meu cotidiano. É fato histórico e social, que a maioria dos homens inferiorizam as mulheres. Mas também é fato que existe a opressão sobre negras e negros, pobres 
e sobre todos os que são diferentes do "mainstream".". A humanidade é muito doida! O homo sapiens conseguiu evoluir domesticando e escravizando plantas, animais, gente, tribos diferentes e, por aí vai. Desde criança, eu queria ser menino. Achava os meninos maravilhosos, hoje, ainda acho alguns! (risos). Na minha infância, eles inventavam brincadeiras muito mais legais que as meninas da minha rua. Sou a caçula de uma geração só de meninos. Eles sempre me colocavam como "café com leite" e, confesso que, não sei até hoje, se era porque eu era a mais nova ou porque era menina. Eu era ágil, corria, jogava queimado, pique-bandeira, jogo de botão, bolinha de gude, fazia natação, atletismo, karatê e gostava muito de lutar. E as mães das minhas amigas, da rua onde eu morava, diziam para não brincarem comigo, porque eu só andava com meninos. Tenho um irmão, cinco anos mais velho, que lia e lê bastante. Aos 14 anos, eu já lia com ele Nietzsche, Sartre, Kafka, Shakespeare e adorava psicanálise. As amigas adolescentes também não gostavam muito de me chamar para as festas. Minhas amigas me achavam estranha, porque para elas, eu sempre estava com um livro "estranho" nas mãos. Aos 16 anos, me apaixonei. Aos 18 anos já estava na faculdade, com uma filha no meu colo. Durante toda a minha graduação fui bolsista do CNPq. Fazia pesquisa sobre Educação Popular. Nunca fui uma ativista feminista. Foi a Educação, a justiça social, a igualdade e a liberdade que me moviam. Quando entrei para o mercado de trabalho, aos 15 anos, eu era alfabetizadora. Alfabetizei presidiários, empregadas domésticas, porteiros, operários. E sempre fui muito respeitada. Só comecei a sentir mesmo a opressão masculina quando entrei para o mundo acadêmico, já adulta, nos anos noventa. Veja só que contradição! Homens intelectuais, mestres e doutores excessivamente vaidosos e machistas. Como homens com tanto conhecimento podem ser tão opressores? A maioria desses homens, desqualificam mesmo, o trabalho intelectual das mulheres. Um absurdo!

NAIARA - Sua concepção sobre feminismo sempre foi a mesma? De quando você teve o seu primeiro contato, até hoje, quando optou por orientar/fazer pesquisas

\footnotetext{
${ }^{3} \mathrm{Na}$ tradução literal, Mainstream significa "corrente ou fluxo principal". A expressão designa os grupos, estilos e movimentos que são dominantes na sociedade.
} 
sobre esse tema, alguma coisa mudou dentro da concepção que já teve em outros momentos da sua vida?

Maria Alice - Eu sou filha da geração de mulheres que atearam fogo nos sutiãs, controlaram a concepção e lutaram pela liberdade sexual. Sou filha das feministas brancas de classe média. Elas foram de suma importância para alcançarmos um outro patamar de luta pela igualdade de direitos da mulher. $O$ feminismo tocou no meu estômago, há 40 anos atrás, com a divulgação na mídia sobre o assassinato de Ângela Diniz ${ }^{4}$. Em 1979, o assassino Doca Street foi condenado por apenas 2 anos, a serem cumpridos em liberdade. O que mais me chocou na época, eu com 16 anos, foi que parte da população apoiava o assassino em nome de uma moralidade descabida. As mulheres se manifestaram: "Quem ama não mata". Então, comecei a ter o conhecimento da violência física dos homens contra as mulheres, independentemente de classe social. A violência simbólica e psicológica, percebi só mais tarde. Quanto a escolha de orientar jovens em suas dissertações de Mestrado sobre o feminismo, penso o seguinte. O que mais me motiva a orientar pesquisas feministas é a oportunidade de ver jovens mulheres relendo e reconstruindo teoricamente o mundo. Isso me dá esperanças. Há cinco séculos os homens brancos europeus tem nos ensinado a interpretar teoricamente o mundo, nos dizendo o que é democracia, liberdade, igualdade, fraternidade e justiça. Esses ideais, do pensamento único masculino da modernidade, não foram, até hoje, cumpridos em sua totalidade. Portanto, acredito que seja necessário um outro tipo de racionalidade - a da racionalidade feminina ou feminista - que possa vir a romper a hegemonia racional masculina e, fazer emergir outra orientação de pensamento emancipatório às velhas premissas masculinas da humanidade. É hora de ampliarmos o nosso conhecimento e interpretarmos o mundo, a partir das experiências de nós mulheres. Acredito que precisamos de todas as cores e saberes de mulheres, para construirmos epistemologias inovadoras e fortes, por meio de nossas visões. Acho que esse é caminho do século XXI.

\footnotetext{
${ }^{4}$ Ângela Diniz (1944-1976), mineira da alta classe social brasileira, era considerada pela mídia como uma "socielite".
} 
NAIARA - O que vocês entendem por feminismo e o que vocês acreditam que ele pode fazer/mudar/transformar no mundo? Vocês acreditam que há possibilidade de se ter realmente um caráter feminista entre candidatas e candidatos às eleições brasileiras, bem como pautas/propostas/políticas públicas de cunho propriamente feminista?

Maria Alice - Como disse Heráclito (Olha, cito um homem! Não tenho referências pré-socráticas de mulheres.): "A única coisa constante e permanente na vida é a mudança". A luta das mulheres será de muitos, muitos anos mesmo! Percebo que o mercado (sim, o mercado capitalista!), já compreendeu que falar e defender os direitos das mulheres dá lucro. Existe também um grande mercado para as mulheres negras, as que atingiram a classe média. Eu já trabalhei com Pesquisa de Mercado e a coisa funciona assim mesmo: o que dá lucro! Existe a Teoria do Agendamento ${ }^{5}$ que pode explicar isso melhor. Posso exemplificar, de forma análoga, a luta pela abolição da escravatura pela Inglaterra, no século XVIII. Não foram os direitos humanos que estava na pauta do Parlamento Inglês pela abolição e, sim, o potencial do mercado consumidor que surgiria com a liberalização da mão-de-obra. Claro, que na época, ondas humanistas abolicionistas estiveram do mesmo lado. Mas, quem deu a palavra final foi o mercado. Se a sociedade civil se fortalecer e vender bem a ideia, o mercado acata e compra. E digo: acata melhor do que o mercado público, que é feudo ainda de parlamentares homens brancos. O mercado capitalista não se baseia no patriarcalismo, e sim no lucro; contudo, o mercado público, da política eleitoral, ainda se pauta no patriarcalismo, porque acha que a coisa pública pertence a esfera masculina. Defino isso como "patrimonialismo parlamentar feminicida". A violência simbólica às mulheres parlamentares está nas entranhas da Política. E, infelizmente, muitas dessas mulheres ainda ficam acuadas. Felizmente, há um movimento, ainda que incipiente, mas genuíno, de mulheres parlamentares contra

\footnotetext{
${ }^{5}$ Teoria do Agendamento (Agenda Setting) explica que os meios de comunicação e seus conteúdos, ao contribuírem para o estabelecimento das agendas políticas e públicas, tem o poder de modelar as representações e as opiniões públicas, utilizando-se de estereótipos para simplificar e distorcer o entendimento de uma realidade, que não está ao alcance do público. Da mesma forma, a Teoria do Agendamento acredita que os poderes judiciário e legislativo tendem a responder aos temas polêmicos, somente depois de os mesmos mobilizarem a atenção pública. Ver: McCombs e Shaw (1972).
} 
isso. Os movimentos sociais de mulheres estão na rua e, pertencem ao mercado eleitoral feminino majoritário e em expansão. Contudo, o dinheiro partidário ainda está nas mãos dos homens. Em minha opinião, as mulheres precisam usar toda a sua energia política pulsante não apenas por programáticas dirigidas somente às mulheres; mas sim, uma luta pelo acesso efetivo e de qualidade aos equipamentos coletivos por todas brasileiras e brasileiros, tais como: saneamento básico, saúde, educação, trabalho, habitação, terra, justiça e mobilidade urbana, bem como lutar contra a tamanha desigualdade social e econômica que temos em nosso País. É uma agenda complexa que requer uma diversidade de atores sociais. Acredito que $o$ movimento feminista tem força para pensar e pressionar essa agenda de políticas públicas, de forma ampla. Por exemplo, sou a favor pela legalização do aborto. Mas, se não tivermos uma saúde pública de qualidade, de nada vai adiantar a legalização. Para mim, essas são as agendas que precisam ser fortalecidas no Brasil, por todas nós mulheres brasileiras, feministas ou não.

Maria Alzira - Desde criança, eu não concordava com a maior parte da opinião das mulheres que não davam a devida importância ao papel do homem na vida familiar. Algumas dessas mulheres, viam o marido como chefe de família, desde que tivesse dinheiro para o sustento familiar. Se desse dinheiro, tudo estava bem. Porém, em minha opinião, esse dinheiro poderia ser dado por outra pessoa, por exemplo, um grande amigo, um amante, um avô. Isto é apenas uma contribuição material. $O$ feminismo para mim também é reconhecer o importante papel do pai e do marido: o amor, a compreensão, o afeto que ele dá ou deveria dar aos filhos e à família. Para mim, feminismo é um movimento que visa a igualdade de direitos entre homem e mulher. Quanto à programática política eleitoral, para mim é muito difícil emitir qualquer opinião a respeito das próximas candidatas. Por enquanto, minha resposta é: Não sei!

MARIA ALICE - Vocês já pensaram na possibilidade de o Feminismo vir a ser (em algum momento da História) o outro lado do Machismo, atuando da mesma forma, a partir da opressão e dominação das mulheres sobre os homens? 
Monique: Não, porque o feminismo em si nunca propôs isso. Importa ressaltar que a teoria feminista faz uma distinção entre dois conceitos: Femismo e Feminismo. A primeira diz respeito a essa inversão de dominação masculina pela dominação feminina. O Feminismo preza pela igualdade de acesso aos direitos, principalmente, àquelas mulheres que, historicamente, viveram uma situação de opressão e subjugação pelos homens.

Naiara: Não. A concepção do feminismo como o inverso do machismo não é comum a quem compreende as bases do movimento/teoria feminista. Mesmo as vertentes mais radicais, de que tenho conhecimento, não chegam a cogitar chegar ao nível de violência estrutural que o machismo possui. Certa vez li uma frase que dizia: "Se eu quisesse igualdade, agrediria um homem a cada $5 \mathrm{~min}$, o que eu quero é o fim das violências contra as mulheres". Acredito que essa frase possa explicar bem a confusão que se faz entre machismo e feminismo. Ela demonstra o uso do termo "igualdade" como provocativo, apresentando a diferença radical entre a consequência do machismo e os objetivos da luta feminista. Um não é o inverso do outro. Seus objetivos não são contrários, são substancialmente diferentes. A finalidade do machismo se define pela dominação e manutenção de privilégios, apenas aos homens; ao contrário, o anseio do feminismo consiste na luta por iguais direitos e oportunidades entre homens e mulheres. Não se trata da superioridade das mulheres. Por isso, não penso que o Feminismo, um dia, possa vir a operar da mesma forma que o machismo.

MARIA ALICE - Vamos voltar ao tempo. Desde a Antiguidade Greco-Romana, como o berço da Democracia, depois a supremacia da Igreja Católica à formação do Estado Moderno e à consolidação do Capitalismo, a História veio sendo interpretada, contada e disseminada, hegemonicamente, pelos homens europeus. A humanidade tem sido contada como a representação do homem. O pensamento do homem predomina na imagem de temos sobre a Humanidade. Vocês acham que a Teoria Política Feminista contemporânea pode fazer uma releitura teórica da 
História? O que o olhar feminino pode ensinar à essa interpretação hegemônica e masculina da História da Humanidade?

Monique: Várias releituras da História podem e são feitas, o tempo todo. A História que costumamos ver nos livros didáticos, mais tradicionais, é a do ponto de vista do colonizador. É a dita história dos vencedores e, predominantemente, realizada pelo homem branco, europeu e heterossexual. No caso do Brasil, essa história alia-se com a visão moral católica ditada desde a nossa colonização. Ainda hoje, muitos desses preceitos estão arraigados na formação cultural brasileira. Contudo, as mulheres sempre estiveram presentes nos mais variados momentos de decisão histórica como a Revolução Francesa, a Revolução Russa, a Guerra pela independência no Brasil, Canudos, dentre outras. Entretanto, sempre nas páginas dos livros foram ignoradas. Nesse sentido, acho de fundamental importância o olhar histórico que venha a inserir o protagonismo não só das mulheres, como também dos indígenas e negros.

Naiara: Sim, não tenho dúvidas quanto a isso. A leitura hegemônica da História serviu para manter diversas opressões - étnicas, raciais, religiosas, e outras - como à opressão às mulheres. Acredito que algumas das maneiras de transformar essa realidade, é a de caminhar para o fim dessas subalternizações, seja pela releitura da trajetória da humanidade - reconhecendo essas violências - para saber como não as reproduzir; e, principalmente, possibilitando que as próprias afetadas e os próprios afetados possam falar por si, como autoras e autores da própria história e melhores conhecedoras e conhecedores do reflexo dessa invisibilização. Acredito que o olhar das mulheres pode/poderá localizar e evidenciar a profundidade dessas opressões e, assim, apontar caminhos para diminuí-las cada vez mais, até a transformação completa da realidade em que vivemos.

Maria Alzira - Realmente a História é contada mais como um feito masculino. Por quê? Porque o homem teve, de um modo geral, um papel muito mais preponderante do que a mulher, em quase todos os episódios que contam a História da Humanidade. Para citar apenas alguns, mas que foram essenciais para a formação da civilização ocidental. Nas grandes navegações, foi o homem que estava presente desempenhando todas as grandes façanhas que levaram o europeu a colonizar a 
América. Nas guerras que traçaram, muitas vezes, as fronteiras, de muitos dos atuais países, foi ainda o homem que desempenhou o principal papel. Passando para outro plano - as artes. Temos grandes compositores, grandes pintores, grandes escultores. E onde estão as grandes compositoras? As grandes pintoras? Atualmente, a mulher já está aparecendo mais, simplesmente porque está tendo mais oportunidade. Então, isto prova que esta grande contribuição do homem para o desenvolvimento da civilização, não é por sua superioridade; é porque ele sempre teve mais oportunidade do que a mulher. E por quê? Porque se achava que o homem tinha que ser mais bem preparado do que a mulher. Desta forma, os pais, os governos investiam, praticamente, só na educação masculina. Este modelo durou muitos séculos! Por isto, a História é mais masculina do que feminina.

MONIQUE - Como vocês acham que é possível fazer um trabalho de conscientização, que atinja variados tipos de mulheres na luta e efetivação pelos seus direitos?

Maria Alice - Acho que a conscientização nas redes sociais está indo muito bem. Mas, ainda acho preciso ir para além disso. Ir para as periferias, subir nas favelas, conversar com as mulheres e os homens pobres, negras e negros, com as meninas e meninos. Algumas mulheres já estão fazendo isso. Concordo muito com você quando diz: pela efetivação dos direitos. Devemos sempre lutar pelos nossos direitos, cumprindo nossos deveres como cidadãs. Ainda há muito o que fazer sobre a pobreza e a desigualdade socioeconômica no Brasil. A opressão das mulheres pobres, no Brasil, anda lado a lado com a opressão de gênero.

Maria Alzira - Acho que deve haver um programa de conscientização. Isto porque a própria mulher, às vezes, não se dá conta que está havendo uma discriminação. Senti bem isto, quando vi o filme "A Cor Púrpura" ${ }^{6}$. Estava fazendo um curso de extensão na PUC e, o professor pediu para os alunos assistirem ao filme para debaterem na aula seguinte. No dia em que fizemos a análise do filme, todos os

\footnotetext{
${ }^{6}$ Filme estadunidense de 1985, dirigido por Steven Spelbierg e baseado no romance epistolar da premiada escritora afro-americana Alice Walker, que trata de questões de discriminação racial e sexual.
} 
alunos e alunas - menos eu - comentaram somente sobre o problema do racismo. $\mathrm{O}$ professor me viu calada e me perguntou o que eu achava. Disse que não concordava apenas com o racismo. E ele me pediu para eu expor minha opinião. Eu respondi dizendo que, o mais importante do filme foi o de mostrar a maneira como a mulher é maltratada pelo homem, não importando a raça ou classe social. Claro que mostra o racismo também. O professor bateu palmas: "Isto mesmo!". Então, percebi que várias mulheres ali presentes, não tinham notado os maus tratos a que a personagem principal do filme era submetida. Isto foi secundário ou invisível, para as mulheres que estavam na sala. Cito, mais uma vez, a grande física Marie Curie: "Cada pessoa deve trabalhar para o seu aperfeiçoamento e, ao mesmo tempo, participar da responsabilidade coletiva por toda a humanidade.". Este deveria ser o papel da mulher e do homem. O papel de um ser humano, não importando se é mulher ou homem.

\section{IDEIAS SOBRE O PODER HEGEMÔNICO DOS HOMENS}

MARIA ALICE - Maria Alzira, quando eu tinha meus 17 anos, em 1980, você disse uma frase que me impactou sobremaneira: "Homem não é substantivo, é adjetivo". Eu gostaria que você nos explicasse qual o significado desta sua frase.

Maria Alzira - Substantivo é a palavra que designa um nome, um objeto. Adjetivo é a palavra que designa qualidade. $O$ fato de ser homem já é uma qualidade em nosso mundo machista. Ele é HOMEM, basta, não precisa dizer mais nada. Enquanto nós mulheres, precisamos mostrar e fazer muito, para a sociedade nos adjetivar positivamente.

NAIARA - Considerando que o machismo é estrutural e, que vivemos numa sociedade sob a dominação masculina (patriarcado), como você lida ou lidou com situações em que se percebeu ou foi apontada por estar reproduzindo um comportamento machista?

Maria Alice - Interessante essa pergunta, pois você já parte do pressuposto que vivemos num mundo estruturado pela dominação masculina e, damos eco e voz ao 
patriarcalismo, nas nossas mínimas atitudes. Eu acho que nunca assumi o papel de inferioridade, apesar de reproduzir o machismo de forma inconsciente. Tenho duas filhas mulheres, de 36 e 29 anos. Qualquer vacilo meu, sou chamada a repensar, imediatamente. As mídias têm colaborado sobremaneira nessa nossa revisão de valores. A conscientização do machismo está se expandindo. Por exemplo, antes, essa filha de 36 anos, que hoje já tem 3 filhos, tinha há pouco tempo atrás, uma atitude bem sexista. Meu primeiro neto, filho dela, é homem, nasceu em 2010. Ou seja, essa mesma filha, que hoje está extremamente atenta ao machismo, há oito anos atrás, me fez trocar a chupeta lilás, que eu tinha comprado para o meu neto: "tem que comprar azul", disse ela na época (risos). Enfim, tenho lidado com serenidade, pois a mudança cultural é lenta e geracional.

Maria Alzira - Já tive comportamento machista, mas em função da própria sociedade que me educou. Não me sinto culpada e, procuro sempre agir racionalmente, isto é, tratando ambos - homem e mulher - da mesma forma.

Naiara - Não me lembro de uma situação em que fui apontada tendo um comportamento machista. Mas sei e lembro de situações em que me vi reproduzindo essas opressões. Não é fácil, principalmente depois que passei a estudar e me afirmar como feminista. Assumir que nossa teoria e prática, algumas vezes destoam, é difícil e frustrante, pois o objetivo é justamente incorporar a teoria à prática. Mas sei que isso é um processo e, me sinto caminhando. De modo geral, busco me corrigir imediatamente e também me desculpar, reconhecendo o erro e levando a experiência com muita seriedade, para não a repetir. Acredito que, o fato de conhecermos as teorias feministas não nos blinda de cometer equívocos. Conhecer e compreender é um avanço e, eu busco a cada dia melhorar mais. Levo pra mim que, não reproduzir o machismo significa vigiar nossos comportamentos, constantemente. É o que procuro fazer. Nesse sentido, concordo com a Maria Alzira: somos educadas pela sociedade para reproduzi-lo. Reconhecer e buscar a mudança é essencial.

MARIA ALZIRA - A participação das mães tem sido, historicamente, muito maior do que a dos pais, na educação dos filhos. E muitas dessas mães, principalmente as da 
minha geração, diziam: " Meu filho não faça isto! Isso é trabalho de mulher!"; " Minha filha venha ajudar sua mãe! ". E assim as crianças cresceram e tornaram-se adultas com este pensamento: "O homem é HOMEM, não pode fazer qualquer coisinha". Em minha opinião, foi a atitude feminina, em grande parte, que formou este conceito. E o que a geração de vocês pensam sobre isso? Será que a mulher gosta de ser dependente do homem? De ter alguém que seja responsável por ela? Hoje, quem educa e como educa os filhos homens?

Monique: O machismo é estrutural. Dessa maneira, ele está arraigado como uma verdade absoluta e inquestionável, principalmente, nas gerações anteriores a minha. Ele perpassa por várias estruturas como o direito, à educação, o casamento. Assim, nessas falas dessas mães que você fala, Maria Alzira, eu vejo um problema de reprodução de comportamento sem reflexão, vindo de uma estrutura a qual essa mulher também estava inserida. Historicamente, às mulheres foram negados os estudos, as diversas profissões, o voto. Essas mulheres foram educadas para achar que sempre deveria haver a figura de um homem por trás, o pai, o marido ou o irmão mais velho. Até fim dos anos 1960, por exemplo, tivemos um Estatuto jurídico, que previa que todas as mulheres casadas só poderiam realizar negócios com a anuência do marido; e, no caso das solteiras que tivessem renda própria, não poderiam realizar negócio em seu próprio nome. Hoje em dia, as coisas estão mudando. Por exemplo, há a concepção de que a educação deve ser realizada por ambos progenitores, com peso igual na educação das filhas e dos filhos. Busca-se uma educação mais inclusiva e menos padronizada, em que meninas não brinquem só com boneca e meninos só com carrinho. A liberdade e preferências têm sido levadas em consideração, atualmente.

Naiara: Não penso que essa é uma responsabilidade direta das mulheres. A nossa submissão à esfera/afazeres domésticos, bem como aos homens, não foi uma ação voluntária e espontânea por parte das mulheres. Para mim, trata-se de uma relação de força e desigualdade de poder que usou/usa da cultura para se perpetuar enquanto "normal" /natural. Assim, não vejo essa concepção como responsabilidade das mulheres; mas, de uma cultura patriarcal e machista introjetada nessas concepções de ver e estar no mundo. Portanto, vejo essas mulheres como 
reprodutoras do sistema dominante; e, não como responsáveis pela existência dele. Acredito que, parte da minha geração, consegue observar isso e, já esteja tentando mudar essa realidade. Nesse sentido, acredito que a educação dos filhos ainda é relegada majoritariamente às mulheres. Retomo, porque essa é uma questão estrutural, em que pessoas e instituições agem e se preparam apenas para reproduzir isso. Sobre as mulheres gostarem de ser dependentes dos homens ou terem alguém responsável por elas, eu acredito que abarque outras questões, na medida em que essa "dependência" traz consigo limitações à autonomia e direitos em geral. Essa pergunta não é tão simples. Se formulada de outra maneira, como por exemplo: "Vocês querem perder direitos e autonomia, para dependerem de um homem?". Eu imagino que a resposta poderia ser, em sua maioria, negativa. $\mathrm{Na}$ tentativa de criar estereótipos e manter o patriarcado, diversas ciências já tentaram explicar o comportamento das mulheres com base em patologias. Em 1981, por exemplo, o livro chamado "Complexo de Cinderela", de Colette Dowling, buscou embasar a dependência das mulheres através da psicologia, afirmando "o medo oculto que as mulheres tinham da independência" e de seu "desejo em ser salva". Nessa década, muitos estudos foram escritos para explicar essa codependência como uma síndrome tipicamente feminina. Felizmente, atualmente, alguns estudos feministas oferecem subsídios para desmistificar esse posicionamento. Portanto, entendo que esse foi o entendimento de uma época. Mas, hoje, não se sustenta. Portanto, enquanto feminista que acredita na necessidade de emancipação das mulheres, eu não entendo que as mulheres queiram (no sentido de desejarem) ser dependente ou ter um homem como responsável por elas. Mas ressalto que, aceitar essa situação decorre da manutenção de um sistema que coloca isso, às vezes, como única ou melhor opção para as mulheres, como sustentado por algumas religiões, por exemplo.

Maria Alice - Maria Alzira, a minha geração também herdou essas mazelas. Como fui mãe na adolescência, foi muito difícil para mim, superar essas crenças. Até que um dia, uma tia querida me ajudou, há 34 anos atrás, quando perguntei sobre como educar a minha filha para ser feliz. E ela me disse: "para você fazer sua filha feliz, você precisa ser feliz. Não podemos dar o que não temos". Lembro como se fosse 
ontem. Estávamos dentro da água do mar, na praia da Urca (Rio de Janeiro). Ela chegou a exemplificar de maneira simples: "Maria Alice, me dá uma maçã, agora.". E eu disse, "eu não tenho uma maçã para te dar". Ela concluiu: "Para você fazer sua filha ou quem quer que seja feliz, você primeiro tem que ser feliz, ter felicidade para dar. Não podemos dar aquilo que não temos". Nesse dia, essa minha tia me salvou, me libertou para eu ser o que desejasse ser, sem medo de ser feliz. A partir de então, comecei a cobrar a responsabilidade do pai da minha filha, pois eu estudava e trabalhava. E ele também foi aprendendo a compartilhar responsabilidades na educação de nossas filhas. Essa tia querida que vos falo, é você, Maria Alzira. (silêncio emocionado).

MARIA ALICE - Uma ideia que me parece ser bem masculina é: "se quer a paz, prepare-se para a guerra". Como vocês, mulheres feministas, entendem o imperativo hipotético desta frase?

Monique: Não vejo como uma guerra, mas uma revolução de pensamento que, por si só, demanda de mais tempo para propor a ruptura com velhas estruturas e dogmas. Nós mulheres, precisamos propor uma desconstrução do que muitos encaram como verdades absolutas e, fazer um pensar sob novos prismas.

Naiara: Essa frase me remete muito à redução das formas de vida apenas baseadas na violência. A ideia de violência como fim para a paz me parece limitada e contraditória. Como pesquisadora, acredito que transcender à agressividade como meio de transformação social é indispensável. Mas, não acredito que essa concepção derive do fato de ser mulher e feminista. Mulheres também defendem a guerra - como podemos observar em algumas lideranças políticas - então não compreendo a concepção como "masculina", mas concordo que a relação que se faz entre homens e guerra é bastante forte.

Maria Alzira - Eu vejo isto como o "se preparar para a guerra" é o mesmo que ter e assumir um poder. Um poder tal, que possa vir a evitar ou mitigar o predomínio, a força e vontade de enfrentar um outro poder para submetê-lo. Portanto, "se preparar para a guerra" é mostrar poder, que possa vir gerar a Paz. 
Maria Alice - Eu acho que essa ideia de guerra, principalmente, a guerra bélica é, bem machista. Vejo, hoje, que estamos vivendo um momento de grande tensão, de polarização política. Isso é bom, porque estamos trazendo a política de volta ao palco. No Brasil, em particular, estamos vivendo um momento que defino como "entropia social". O conceito entropia, originário da Lei termodinâmica da Física, não significa uma "desordem", mas sim uma variação dentro de um sistema. Desta forma, essa "entropia social" para mim, significa que estamos vivendo uma temperatura quente em que divergentes, ambíguas, contraditórias e diversas opiniões estão pulsando na vida política brasileira. E essa entropia, em algum momento, vai se estabilizar e se equilibrar. $\mathrm{E}$, mais à frente, novas entropias sociais surgirão. Estamos em processo de redemocratização. Mas, confesso, que me sinto, às vezes, triste com posicionamentos violentos, arrogantes; e, até mesmo discriminatórios enfrentados pelas pessoas que pensam ou são diferentes. Eu tenho presenciado condutas violentas de mulheres jovens e, desta forma, me faz refletir até que ponto estamos reproduzindo, mesmo que com outro discurso, as guerras bélicas produzidas pelos homens. Observo comportamentos de alguns grupos sociais de mulheres que vem construindo uma identidade defensiva e segregacionista, acentuando a homogeneidade de seus membros, concebendo que somente seja possível a relação social entre iguais. Fico preocupada se as reivindicações destes grupos venham pulverizar a força do movimento feminista pela igualdade de direitos da mulher.

MARIA ALZIRA - Os seres humanos (homens e mulheres) surgiram e evoluíram sobre a Terra, ambos com a mesma capacidade intelectual. Contudo, biologicamente, a maioria dos homens é mais forte - fisicamente - do que a mulher. Você acha que isto pode ter sido o primeiro passo para se construir o mito da superioridade do homem?

Monique: Sim, o mito biologizante foi usado e, ainda é - infelizmente - nos dias de hoje, para determinar várias características que, na verdade, são culturalmente construídas e impostas sobre nós. Sobre o assunto, temos como exemplo o 
pensamento da bióloga e filósofa norte-americana Donna Haraway ${ }^{7}$, no sentido de questionar essa visão que a própria biologia utiliza para explicar fatos que, muitas vezes, são culturais.

Naiara: Não sei se foi o primeiro, mas concordo que foi utilizado. Assim como a psicologia, a biologia e outras ciências se empenharam em dar um teor científico às formas de dominação. Um exemplo disso é o uso da craniometria como fundamento do determinismo biológico, que tentava explicar a inferioridade das pessoas negras pela medição da caixa craniana. ${ }^{8}$ Portanto, acredito que esse argumento foi utilizado sim. Mas desconfio que ele decorra de um fato puramente biológico. Diferente da gestação e menstruação, a musculatura pode ser desenvolvida pelas atividades que desempenhamos e, historicamente, as mulheres não foram incentivadas a realizar práticas que dispunham de força, por isso me pergunto: será isso um fato biológico ou socialmente construído?

Maria Alice - Eu acho realmente que os homens se utilizaram da menor força física das mulheres e da maternidade, para construírem histórica e socialmente o mito da inferioridade feminina. Mas, podemos também acreditar que, no processo evolucionista da humanidade, essa fragilidade pode ter sido produzida, de alguma maneira, como talvez o tipo de comida ingerida pelas mulheres, há milhões de anos atrás. Não sei ao certo. Mas sei que o hormônio testosterona é encontrado em maior quantidade nos homens. Esse hormônio tem efeitos anabolizantes sobre o crescimento de massa muscular e do aumento da densidade e da força óssea. Sendo assim, os homens tiveram o hormônio testosterona como aliado fundamental para construir socialmente essa pretensa supremacia. A intelectual francesa Simone de Beauvoir quando publicou a obra "O Segundo Sexo", em 1949, escandalizou o mundo. Ela apresentou fatos e mitos sobre as mulheres, analisando por meio de múltiplas perspectivas, tais como: a biológica, a psicanalítica, a materialista, a histórica, a literária e a antropológica, esclarecendo que as explicações científicas da inferioridade da mulher foram construídas pelos homens para definir a mulher como "outra" coisa, diante do poder masculino. Temos também a autora norte-americana e

\footnotetext{
${ }^{7}$ Ver: Haraway (1995)

${ }^{8}$ Para ver mais sobre racismo científico ver: Gould (1991). 
ativista feminista dos anos 1960 e 1970, Evelyn Reed, em seu livro "Is Biology woman's destiny?" (1971), que mergulhou na explicação da origem da opressão da mulher, demonstrando suas raízes históricas e derrubando os mitos sobre a inferioridade do sexo feminino e a ideia do "segundo sexo". Segundo essa autora, desde os seus primórdios, há cerca de dois mil anos, essa crença na inferioridade feminina foi construída, difundida e perpetuada pelo Estado, pela Igreja e pelas instituições familiares que serviam aos interesses dos homens. Portanto, desmistificar a inferioridade feminina ainda é um longo caminho para desmistificarmos um erro construído pelo universo científico masculino branco e europeu.

\section{O VIVER E O SENTIR MULHER, NUM MUNDO MACHISTA}

MONIQUE - Vocês veem diferença entre o tratamento, as limitações e oportunidades enquanto mulheres de hoje e quando eram mais jovens? Se sim, quais?

Maria Alice - De acordo com as minhas experiências e com o meu meio século e meia década de existência percebo, hoje, tudo mais difícil e complicado. Quando jovem, pude lutar e sonhar por uma democracia. Fui uma militante na Educação, em particular na Educação Popular. Trabalhei com o Darcy Ribeiro, subi e desci favelas e sonhei com uma Educação para todos e de qualidade. Estudei em ótimas escolas públicas no Ensino Fundamental e Médio. Estudei com colegas que moravam nas Favelas do Vidigal, da Rocinha e da Praia do Pinto, antes de ser incendiada. Mas, quando cheguei na Universidade Pública, esses meus colegas não estavam lá. Aliás, nesta época, encontrei um colega do antigo ginásio (Ensino Fundamental) que vivia na Favela. Sabe onde o encontrei? Vendendo picolé na praia. Sou branca, de classe média, filha de servidores públicos, morava na zona sul do Rio de Janeiro. Sou uma privilegiada. Entretanto, como já mencionei, fui mãe antes de entrar na Universidade. Vocês acreditam que fui discriminada por várias colegas mulheres do Curso de Ciências Sociais por ser mãe? Mas, segui em frente. Fiz mestrado, doutorado, pós-doutorado e trabalhei como pesquisadora no Centro de Estudos Sociais da Universidade de Coimbra, com um sociólogo bastante conhecido. Vocês 
acreditam que algumas "amigas" brasileiras chegaram a me perguntar o que eu tinha feito para ter conseguido trabalhar com ele; e, chegaram a me perguntar: "Fala a verdade, você dormiu com ele, não foi?". Acho que essa foi demais para mim, porque veio de uma mulher. O mercado matrimonial gerou essa disputa entre as mulheres da minha geração. Fico muito feliz quando, hoje, encontro a "sororidade". Nem que seja apenas no discurso, já é um grande avanço entre nós. Enfim, tive muitas oportunidades na vida e as conquistei com toda a garra. As limitações foram na jornada cotidiana. Tive que aliar a maternidade precoce, com duas filhas, com o casamento, com o trabalho profissional, com os cuidados com a casa e, tantas outras coisas. Eu me concentrava mais nas oportunidades, do que nas limitações. Caso contrário, eu não conseguiria seguir os meus objetivos. Os obstáculos e as limitações fazem parte da vida. Cabe a cada uma de nós, termos estratégias inteligentes e éticas para superá-las.

Maria Alzira - Lógico, que há uma diferença muito grande! Na geração de minha mãe, as mulheres eram educadas para agradarem. Tinham que casar e tinham que fazer tudo que o marido quisesse. A vida era em função do homem. A mulher ter uma profissão e dar valor à profissão não era uma atitude vista com bons olhos. Já na minha geração, mudou um pouco. As mudanças eram feitas vagarosamente, mas eram feitas. A mulher podia escolher uma profissão, desde que, não esquecesse que seu objetivo principal na vida: ter um marido. Este não foi o meu caso, porque meus pais e, também o meu marido, não pensavam desta maneira. Pude conciliar as duas coisas: marido e profissão. Havia também, na minha época, duas maneiras de se tratar a mulher: em sociedade e em casa. Em sociedade, a mulher era tratada muito gentilmente - era a época de puxar a cadeira para a mulher sentar; abrir a porta para ela passar; beijar a mão quando a cumprimentava; jamais falar uma palavra grosseira quando uma mulher (de qualquer idade) estivesse presente. Em casa, a situação era outra: palavrão ninguém falava diante de uma mulher, mas ela era tratada como um objeto que não poderia resolver nada muito importante (como se a educação de uma filha não fosse algo muito importante). Em minha opinião, o que realmente mudou o comportamento da mulher, foi a pílula anticoncepcional. No momento em que a mulher não tinha mais o perigo de ficar grávida, ela estava 
quase tão livre quanto o homem. Quase, porque a sociedade ainda cobrava um comportamento feminino diferente do comportamento masculino. Mas este, foi o primeiro passo para cortar as amarras da mulher.

MONIQUE - Vocês já sofreram algum tipo de violência (física, psicológica) em relacionamentos? Como se sentiram enquanto mulheres nessa situação? Maria Alice - Felizmente, nunca fui vítima de violência física. Mas, psicológica sim: "Você está louca! Está na TPM!" Confesso que, algumas vezes, pensava: "Será que estou falando isso, porque estou na TPM?". As vezes estava mesmo! Mas, e daí? A TPM pode até nos dar mais clareza e energia quando falamos. Os homens utilizam também do hormônio testosterona para justificar a sua força, por vezes, brutal. Já ouvi muitos homens dizerem: "tal mulher é assim (quando exigia respeito ou colocava suas opiniões com firmeza) porque é feia e não tem homem, é malamada". Nossa, já ouvi muitos homens falando isso! Absurdos do mundo machista. Já ouvi muitos depoimentos de alunas (crianças, jovens e adultas), que foram estupradas e sofreram violência doméstica. Choramos juntas. Quando essas alunas/mulheres eram adultas, eu as apoiei para terem coragem para tomar atitudes legais. Já ouvi casos de alunas adolescentes, de 12 anos, que me contaram que haviam sido estupradas pelo padrasto e, que suas mães a expulsaram de casa, dizendo que eram elas quem assediavam os padrastos. Nesses casos, tive que intervir de maneira forte e institucionalmente. Muito triste! Já ouvi muitos desses tipos de casos.

Maria Alzira - Felizmente, nunca. Para mim, isso é inimaginável.

MONIQUE - A misoginia está presente, por exemplo, quando se associa às mulheres a loucura e a histeria, como se houvesse uma predisposição que conferisse a nós mulheres, uma inconfiabilidade natural. Já houve momentos em que você se sentiu silenciada, invisibilizada ou cerceada por esses artifícios misóginos? Como se sentiu?

Maria Alice - A misoginia é uma forma de repulsa, desprezo, ódio e aversão mórbida e patológica ao sexo feminino. Apesar de não estar catalogada na 
psiquiatria, é considerado uma síndrome, um transtorno crônico psíquico, onde o misógino vive no conflito entre a necessidade do amor por uma mulher e o medo profundo e arraigado das mulheres. A misoginia é a principal responsável por grande parte dos assassinatos de mulheres, como formas de agressões físicas e psicológicas, mutilações, abusos sexuais, torturas, perseguições, entre outras violências relacionadas direta ou indiretamente com o gênero feminino. Porém, nem todos os homens possuem essa patologia. Eu acho que muitos homens têm é medo das mulheres. Eles tentam nos entender e dizem que não conseguem. Essa inabilidade ou incapacidade dos homens nos entenderem em nossa complexidade, gerou um medo. Contudo, tenho percebido que, alguns movimentos feministas, tem banalizado, naturalizado e generalizado essa patologia a todos os homens. Atualmente, para algumas mulheres, basta ser homem para ser misógino. Para mim, os artifícios de silenciar, cercear e invisibilizar fazem parte da estrutura social de relação de poder dos homens sobre as mulheres. Esse poder sim, está profundamente enraizado na história cultural da humanidade há milênios, conforme afirmou a intelectual Mary Beard, em seu livro "Mulheres e Poder: um Manifesto"9. Eu não aceito a ideia de que as mulheres foram passivas e acataram esse poder, milenarmente constituído. Eu acredito que, em algum momento na história da humanidade, as mulheres - por algumas razões - concederam um certo poder aos homens, como por exemplo, na divisão social de trabalho. Mas, isso não significa que as mulheres perderam o poder. Porém, como qualquer poder que se instala e se perpetua, ele pode vir a se transformar em dominação. Os homens conseguiram exacerbar e expandir esse poder, transformando-o em uma dominação patriarcal que se legitimou na dinâmica dialética entre a esfera pública e privada, gerando artifícios culturais materiais e imateriais extremamente maléficos, encapsulados no totalitarismo masculino. Nesse sentido, eu acredito que nos últimos três séculos, as mulheres vêm reivindicando este poder anteriormente concedido. Só nos resta esperarmos o futuro, para saber se esse poder, na prática, será compartilhado entre os homens e mulheres democraticamente, no mesmo grau de igualdade. E

\footnotetext{
${ }^{9}$ Lançado no Brasil em março de 2018, pela Editora Planeta do Brasil. Ver nas Referências.
} 
respondendo a sua pergunta: sim, os homens já tentaram me cercear, silenciar e me assediar moral e sexualmente. No ambiente profissional isso é intenso e terrível.

Maria Alzira - Não, absolutamente não. Se em algum momento, algum homem tentou me silenciar ou me cercear, eu não dei a menor importância. Nunca dei este poder a ninguém. Não permiti ser calada por ninguém e nem por homem nenhum.

Naiara - Sim, mas associo o fato de reconhecer que passei por isso, principalmente depois de compreender realmente o que são e como se dão essas violências. Ouvir que homens com posicionamentos assertivos são fortes; e, que mulheres assertivas e firmes em seus posicionamentos são exageradas/loucas/histéricas me incomodou e me incomoda muito. Minha atuação tanto no movimento estudantil, quanto no período em que estagiei, foi marcada por situações em que a minha fala - e de outras mulheres - somente era validada quando, confirmada ou reproduzida por um homem. A sensação é sempre horrível - um misto de raiva e tristeza - mas na prática, cada situação específica me levou a adotar determinado comportamento. Para mim, ser feminista é também ser estratégica, saber lidar com essas situações conseguindo se posicionar. Evidenciar o machismo presente e, não perder o foco do conteúdo da discussão é um desafio e o meu objetivo como feminista.

MARIA ALICE - Maria Alzira, como foi sua trajetória de esposa de um militar que, de uma maneira ou de outra, imagino que precisou sempre estar ao lado dele, mudando de uma cidade para outra, até mesmo de ter vivido nos EUA, em função da posição dele como Adido Cultural nos EUA? Como ficaram os sonhos profissionais da Maria Alzira?

Maria Alzira - Não houve problema algum, talvez pela minha profissão - o magistério. Em Mato Grosso, por exemplo, não interrompi meu trabalho. Dei aula em um ótimo colégio, durante o tempo todo que passei lá. Nos USA, aproveitei para estudar. Fiz um curso de História do Século XX, no Montgomery College.

MARIA ALZIRA - Gostaria que vocês imaginassem uma amiga, muito próxima, que estivesse grávida e o parceiro afirmou, categoricamente, que não assumiria a paternidade, fato que sua amiga tanto gostaria que ele assumisse. O que vocês 
sentiriam sobre a decisão deste homem? Agora, o inverso. Imaginem se um amigo querido seu, que tanto queria ter uma família e em ser pai, engravidou a namorada. Mas, ela disse que não iria assumir a maternidade. $O$ que vocês sentiriam sobre a decisão dela?

Monique: Em ambos os casos prezo pela liberdade de escolha da mulher, que deve poder decidir sobre seu corpo e sua vida, optando por ter o filho ou não. Apoiaria nesse sentido a decisão da mulher, independente se o parceiro fosse meu amigo ou não. Se ele tanto quer exercer a paternidade, que adote ou - de comum acordo arrume outra parceira, que também tenha o mesmo desejo. Para a amiga que queira ter o filho, mesmo abandonada pelo parceiro, daria total apoio, e ajudaria a conseguir juridicamente, pelo menos, o reconhecimento da paternidade e também a pensão alimentícia para a criança.

Naiara: Antes de responder a cada uma das situações isoladamente, acredito que seja preciso ressaltar que essas situações, apesar de parecerem semelhantes, não são. Ambas carregam expectativas culturais e históricas completamente diferentes, se direcionadas a homens e às mulheres. Pois bem... Na primeira situação, eu me sentiria triste por saber que uma amiga não viu em seu companheiro a parceria que precisava nesse momento. Justamente por saber que o encargo da gravidez é desproporcionalmente superior para a mulher e que, historicamente, essa é uma crença comum dos homens. Eu me sentiria triste e frustrada por saber que a sociedade the cobrará de forma mais intensa as responsabilidades sobre essa criança e a julgará sempre. Seja pela sua honestidade ou capacidade em qualquer outra atividade que vá desempenhar. As responsabilidades afetiva e financeira de uma/um filha/filho sendo direcionada apenas para a mãe, é extremamente cruel. Ficaria muito triste por saber que não posso mudar essa situação e, buscaria apoiála em tudo que pudesse. Na segunda situação, eu também me sentiria triste por saber que meu amigo não viu, em sua companheira, a expectativa que alimentava. Porém, o lembraria que a paternidade exercida isoladamente é vista de forma positiva pela sociedade atual; e, desta forma, ele provavelmente teria apoio - de uma outra mulher, mãe, tia, irmã e o reconhecimento da sociedade, caso optasse por atuar sozinho. O lembraria que essa é uma situação excepcional, se comparada 
com o inverso, onde muitas mulheres vivem isso; e, apesar de passar por dificuldades, conseguem desenvolver essa atividade. Diria que acredito que ele teria condições de levar essa decisão adiante, caso assim decidisse. Ainda assim, ressaltaria que a divisão de responsabilidades afetiva e financeira de uma/um filha/filho, sendo direcionada apenas para um dos responsáveis, é bastante penoso.

Maria Alice - No primeiro caso, apenas perguntaria a essa hipotética amiga se, realmente, ela queria ser mãe, independentemente da decisão e opinião de qualquer outra pessoa. A decisão era só dela. No segundo caso, eu perguntaria se ele sabia qual a razão de ela não querer assumir a maternidade. Consigo imaginar somente três opções: uma, seria que ela não queria ser mãe com ele; outra opção é que ela não desejava ser mãe naquele momento de sua vida; ou, simplesmente não queria ser mãe. Eu lamentaria nos dois casos, em função de que provavelmente ficariam frustrados em seus planos. Mas, para mim, a decisão de ser ou não ser mãe, ainda é da mulher. Gostei da pergunta, porque me sinto desconfortável em ter uma decisão monocrática sobre a maternidade.

\section{SER MULHER}

A última pergunta, provavelmente, a mais importante deste artigo, foi proposta pela Maria Alzira, para que todas nós respondêssemos: O que é SER MULHER para você?

Monique: Para mim, ser mulher é ser forte. É precisar ser forte, para compreender que vários tipos de acesso nos sãos negados; que mulheres morrem só por serem mulheres; em que a cultura do estupro é presente; em que aborto, emancipação e escolhas sexuais ainda são tabus. É lutar pelo fim dessa opressão absurda! É dar as mãos numa luta, em que vários tipos de mulheres geram a necessidade de muitos tipos de feminismos: como o feminismo negro, marxista, decolonial, pósestruturalista. $^{10}$ E seguir nessa busca, por nós mesmas.

\footnotetext{
${ }^{10} \mathrm{O}$ feminismo marxista é o ramo do feminismo focado a explicar as maneiras pelas quais as mulheres são oprimidas por meio do sistema capitalista e da propriedade privada (SAFFIOTI, 2004). O feminismo decolonial propõe, de forma geral, uma lente que nos permita ver o que está escondido em nossas compreensões sobre questões de raça e gênero; e, sobre as relações de cada
} 
Naiara: Considero essa a pergunta mais difícil. Com receio de incorrer em qualquer resposta biológica, preconceituosa ou que acabe por reforçar tanto os estigmas sociais da representação do que é feminino, quanto os estigmas que romantizam nosso lugar de luta (que só existe pela opressão que sofremos), pretendo responder essa questão da forma mais individualizada possível, buscando não desrespeitar nenhuma outra compreensão. Enfim, para mim, ser mulher é um grande paradoxo. É considerar-me fonte da vida - transcendência e fascínio - e, ao mesmo tempo, força e resistência constantes. Para me fazer melhor compreender, compartilho do pensamento/trabalho de Gilka Machado, de $1915^{11}$ :

\section{Ser mulher}

Ser mulher, vir à luz trazendo a alma talhada para os gozos da vida; a liberdade e o amor; tentar da glória a etérea e altívola escalada, na eterna aspiração de um sonho superior...

Ser mulher, desejar outra alma pura e alada para poder, com ela, o infinito transpor; sentir a vida triste, insípida, isolada, buscar um companheiro e encontrar um senhor...

Ser mulher, calcular todo o infinito curto para a larga expansão do desejado surto, no ascenso espiritual aos perfeitos ideais...

Ser mulher, e, oh! atroz, tantálica tristeza! ficar na vida qual uma águia inerte, presa nos pesados grilhões dos preceitos sociais!

Maria Alice - A resposta da Naiara com esse poema lindo, me inspirou. Fiquei pensando em qual poema escolher. E decidi optar por uma música da Rita Lee, que retrata a minha geração. Vou citar alguns trechos da música "Cor de rosa Choque".

qual à heterossexualidade normativa, combinada com um olhar das lutas e trajetórias das mulheres nascidas em países colonizados (LUGONES, 2014). No feminismo pós-estruturalista é feito uma crítica aos conceitos reconhecidos como universais e vindos do racionalismo iluminista (MOUFFE, 1999).

${ }^{11}$ Gilka Machado foi uma poetisa feminista brasileira que lutou pelo direito ao voto no Brasil e fundou o Partido Republicano Feminino, em 1910, quando as mulheres ainda não tinham o direito de votar. Além dessa transgressão, Gilka ficou conhecida por ser a primeira brasileira a escrever poesia erótica. 
Essa música "bombou" nos anos oitenta! Ficava muito feliz dançando e cantando essa música (risos):

Nas duas faces de Eva

A bela e a fera

Um certo sorriso de quem nada quer

Sexo frágil

Não foge à luta

E nem só de cama vive a mulher

Por isso não provoque

É cor de rosa choque

Não provoque (...)

Mulher é bicho esquisito

Todo mês sangra

Um sexto sentido maior que a razão

Gata borralheira

Você é princesa

Dondoca é uma espécie em extinção

Por isso não provoque

É cor de rosa choque

Não provoque (...)"

Maria Alzira - Ser mulher é ter certeza de que, ao mesmo tempo, em que está vivendo a sua vida, está contribuindo para o desenvolvimento da Humanidade com o seu trabalho, seu pensamento e sua sensibilidade. É ter equilíbrio emocional de modo a poder enfrentar qualquer situação, por mais difícil que seja. Não se importar com a opinião alheia, se esta opinião não afetar a sua vida. Reconhecer que o homem é tão importante quanto ela, na construção da felicidade de uma família. Compartilho com a ideia da minha neta Luiza Noli Silveira, de 28 anos, que um dia me disse que ser mulher "é sonhar em ser livre e fazer o que quiser.".

\section{CONSIDERAÇÕES FINAIS}

Este artigo teve como objetivo dar voz às mulheres de três gerações, a partir de uma conversa sobre as opiniões que tem sobre suas vidas. Importa ressaltar que, 
essas mulheres pertencem, hoje, à classe-média $B$ e $C^{12}$. Suas famílias conquistaram uma renda por meio de muito trabalho e esforço, que as possibilitaram a ter uma expectativa de vida com menor privação, com uma formação escolar de Ensino Superior, adquirindo bens e controlando os seus gastos com prudência. Os estudos e o trabalho são valores de suma importância para essas mulheres, na medida em que representam a possibilidade de prosperar e conquistar direitos, valorizando o esforço próprio. Elas são oriundas das regiões sul (Paraná) e sudeste (Minas Gerais e Rio de Janeiro) no Brasil que, apesar das assimetrias territoriais internas, são as regiões mais ricas do País.

Desta forma, as interpretações dessas mulheres, como de qualquer outra pessoa, são delimitadas, pois depende de que lugar estão vendo e falando. Existe uma pluralidade de perspectivas de diferentes etnias, religiões, gêneros, classes e de diferentes culturas. Cada um olha de acordo com a sua imaginação, a sua cultura e a sua classe social. Portanto, existe aquilo que não queremos ver ou aquilo que não conseguimos olhar. Consequentemente, tornamos invisível o que não podemos olhar. Não existe neutralidade axiológica no olhar. Só olhamos o que nos é apropriado a enxergar e o que está em sintonia com a nossa visão de mundo. Olhamos o mundo através de um espelho. $O$ reflexo em um espelho não é de modo algum a coisa que é, apenas parece ser. Essa é a metáfora do mundo que olhamos.

A partir da análise realizada sobre as perguntas e respostas deste artigo, podemos tecer algumas considerações. As mulheres entrevistadas, neste artigo, com 88 e 55 anos retratam que o passar dos anos influi diretamente na educação de cada uma e nas suas decisões e posições, enquanto mulher. A diferença de 33 anos, entre elas, se apresenta de forma relevante nas questões sobre profissão, família e comportamento.

Cada uma delas nasceu no auge das duas primeiras ondas feministas; e, em dois momentos históricos emblemáticos no Brasil, de ditaduras: a de 1937 (Governo Vargas); e, em 1964 (Ditadura Militar). A primeira, cresceu quando as mulheres brasileiras intelectuais e de elite buscaram o acesso aos espaços públicos pelas vias

12 Segundo a classificação das classes sociais do IBGE (instituto Brasileiro de Geografia e Estatística). Ver site: <https://www.ibge.gov.br/index.php>. 
institucionais formais. Em 1932, o Brasil garantiu o direito de as mulheres votarem e serem votadas. Além disso, as das classes sociais e econômicas mais favorecidas, podiam ter uma profissão, caso desejassem e/ou o pai ou marido consentissem. Dessa forma, a educação e socialização dessas mulheres ainda não permitia que elas utilizassem estratégias radicalmente transformadoras. Contudo, as mulheres de classe alta, puderam visualizar questões mínimas de autonomia, como estudo e profissionalização; contudo, essas escolhas eram ainda bastante limitadas, consideradas somente "adequadas", as profissões como o magistério e algumas áreas da saúde, como a enfermagem. Ainda assim, a resistência e desenvolvimento intelectual das mulheres pode ser registrada, por exemplo, pela história de $\mathrm{Pagu}^{13}$, escritora brasileira e primeira mulher presa política.

A entrevistada de 88 anos reconhece que sua época foi marcada por uma educação mais conservadora e machista, do que hoje. Ela tem clareza que o mundo não é igual para homens e mulheres, mas que deveria ser. E, à sua medida, age para que isso aconteça. Se interessa pelas mudanças que as novas gerações trazem e se põe aberta, para questionar e ser questionada.

A entrevistada nascida na década de 60 , reverbera em suas falas, outro contexto histórico do movimento feminista. O movimento cultural reivindicatório feminista realizado no âmbito internacional teve um grande e forte impacto no mundo, inclusive no Brasil. A invenção da televisão proporcionou uma maior extensão das notícias que circulavam no mundo. Pode-se ver, pela televisão, o "homem"14 chegando na Lua. Um grande movimento de crítica cultural, pelas mulheres em 1968, foi impulsionado principalmente, pela criação do método da pílula anticoncepcional, pela indústria farmacêutica norte-americana, em 1960. As feministas queimaram sutiã e levaram, a público, o seu desejo de liberdade sexual.

\footnotetext{
${ }^{13}$ Pagu é o pseudônimo de Patrícia Rehder Galvão, escritora, poeta, diretora de teatro, tradutora, desenhista, cartunista, jornalista e militante política brasileira, que viveu entre 1910 e 1962.

${ }_{14}$ Colocamos entre aspas a chegada do "Homem" na Lua, porque demonstra que - apesar dos movimentos das mulheres terem se intensificado nos anos 1960/1970, as mulheres negras e pobres ainda ficaram invisíveis. Podemos ilustrar este fato com o filme "Hidden Figures" (Figuras Escondidas), estreado recentemente, em 2016, no Brasil, com o título "Estrelas Além do Tempo", que conta a história de três cientistas mulheres e negras norte-americanas (Katherine Johnson, Dorothy Vaughn e Mary Jackson) que contribuíram, sobremaneira, para a chegada dos Estados Unidos da América na Lua.
} 
A revolução cultural dos anos 1960, gerou mudanças importantes em que as mulheres puderam conquistar e desfrutar de alternativas de estudo e trabalho. Ainda assim, eram as mulheres de classe alta, a possibilidade de acesso à uma Educação de qualidade, de consumo e de práticas, anteriormente, consideradas masculinas. Desta forma, a entrevistada de meia idade, representa as mulheres de tiveram acesso a essas transformações culturais e sociais. Portanto, ainda representa um número ínfimo de mulheres que atingem a pós-graduação, como o pós-doutorado, por exemplo.

É possível percebermos que ela esteve presente em momentos de grande mudança no país. Pode ver e participar de transformações no Brasil e, levou isso para sua vida. Teve condições financeiras de se capacitar profissional e academicamente, oportunizando maior senso crítico diante da desigualdade entre homens mulheres, mesmo não se autodeclarando feminista. Ainda que se interesse pela teoria feminista, se dispondo a proporcionar e analisar estudos sobre o tema, permitindo tanto questionar quanto ser questionada; ela, ainda sente e retrata certos incômodos por alguns movimentos feministas.

Podemos encontrar um denominador comum entre as mulheres mais velhas. Elas saíram um pouco do estilo convencional de suas épocas, na medida em que conquistaram uma posição social na esfera pública, independentemente do homem. Contudo, ambas estão em conformidade com o modelo de mulheres dedicadas à família e à maternidade, tendo como referências importantes na vida a família, o pai, o marido e o irmão mais velho. Em alguma medida, a mulher de meia idade sente um certo estranhamento de parte de alguns movimentos feministas atuais; o que pode sinalizar positivamente que os movimentos feministas atuais, ao mesmo tempo, em que causam perplexidade também geram, concomitantemente, uma força para as mulheres resistirem aos estereótipos de subalternização.

As jovens entrevistadas representam a face de uma parcela das mulheres da classe média brasileira, da faixa etária entre 19 e 30 anos, com ensino superior. Suas ideias e pensamentos, em alguma medida, retratam os resultados e o espírito de dois cenários importantes, no contexto internacional e nacional. No contexto mundial, as décadas de setenta e oitenta se desenvolveram inspiradas pela temática 
da cidadania e dos direitos humanos. Temos, como exemplo, a primeira Conferência Mundial da Mulher, patrocinada pela ONU, em 1975. Nesta Conferência, o lema foi "Igualdade, Desenvolvimento e Paz", aprovando um plano de diretrizes de ações para os governos e a comunidade internacional para o decênio 1976-1985, destacando: a igualdade plena de gênero e a eliminação da discriminação por razões de gênero; a plena participação e contribuição das mulheres no desenvolvimento e para a paz mundial. Na terceira Conferência (1985), mais perto das mulheres jovens entrevistadas, o tema central foi um balanço deste decênio, onde se constatou que poucas metas foram alcançadas. Desta forma, foram apontadas medidas de caráter jurídico para o futuro, com o propósito das mulheres alcançarem a igualdade na participação social e política no âmbito internacional. Esse forte caráter jurídico da ONU é representado por ambas: uma advogada e a outra se graduando em Direito.

No contexto nacional, o Brasil, no final dos anos setenta, foi marcado pelo processo de redemocratização, ainda em desenvolvimento. Em 1985, foi criado o Conselho Nacional dos Direitos das Mulheres - conectado com o propósito internacional da ONU - que fortaleceu a participação das mulheres no processo constituinte, onde foi apresentada a "Carta das Mulheres Brasileiras aos Constituintes". Esta carta indicou as demandas do movimento feminista e de mulheres. Desta forma, a Constituição de 1988 incorporou no Art. 5 , I: "Homens e Mulheres são iguais em direitos e obrigações (...)"; e, no Artigo 226, no parágrafo $5^{\circ}$ : "Os direitos e deveres referentes à sociedade conjugal são exercidas pelo homem e pela mulher".

Nos anos 1990, no Brasil, em razão da nova Constituição e da Reforma do Estado, foram regulamentados vários dispositivos jurídicos e criados alguns conselhos municipais da mulher. Como não são obrigatórios, pois dependem da organização da sociedade civil, são poucos municípios que possuem Conselhos da Mulher. Esses conselhos municipais, indicados pela Constituição, têm por objetivo criar espaços institucionais, dentro do aparelho governamental, para servir de interlocução entre governos e diversos grupos sociais, para a formulação de políticas públicas. Em 2003, foi criada a Secretaria de Políticas para as Mulheres da 
Presidência da República, com o objetivo de promover a igualdade entre homens e mulheres e combater todas as formas de preconceito e discriminação, herdadas secularmente de uma sociedade patriarcal e excludente. Desde então, algumas mudanças foram estabelecidas: a reforma, em 2009, da Lei n 9.504/1997, obrigando os partidos políticos ou coligações a respeitar o mínimo de $30 \%$ e o máximo de $70 \%$ para candidaturas de cada sexo; a promulgação da Lei Maria da Penha (11.340/2006); a Lei do Feminicídio (13.104/2015); e, a implementação de equipamentos e a capacitação de pessoas para lidarem, principalmente, com mulheres vítimas de violência, dentre outras ações, no intuito de diminuir as desigualdades de gênero.

Desta forma, as jovens entrevistadas nasceram no começo da década de noventa, com a existência de novos dispositivos jurídicos e institucionais a favor das mulheres, mesmo que alguns ainda estejam imbuídos, implicitamente, de tratamento discriminatório e, estejam longe de se concretizarem na vida real, já é um avanço demonstrado nas perguntas e respostas dessas jovens mulheres.

Elas estão vivendo uma geração posterior, em que menos mulheres são "domesticadas" pelo homem, o antigo "chefe" da família. Agora, essas jovens têm se tornado protagonistas, clamando pelos seus direitos, reclamando e denunciando a submissão vivida por uma imensidão de mulheres. Pudemos observar em suas falas, que elas visualizam com clareza o machismo estrutural do mundo, bem como a cultura patriarcal em que vivemos. Elas demonstram ter uma consciência apurada para compreender que, muitas de nós mulheres, ainda sofremos nos encargos domésticos, que poderiam ser compartilhados com os homens. Além de terem informações claras sobre a violência física que as mulheres sofrem, percebem, com muita nitidez, a violência psicológica sistemática e dissimulada que alguns homens reproduzem, tais como: nos silenciar e nos interromper em nossas falas, sinalizando que essas são estratégias machistas, mesmo que subliminares. Elas possuem a consciência da inclusão subalterna das mulheres, seja no ambiente familiar, social e profissional, que nos dá poucas ou ineficazes oportunidades. O mais interessante, dessas jovens mulheres entrevistadas, é que elas não buscam ser iguais aos homens. Elas percebem que ser mulher não é um ser universal e único; pois, há 
diferenças culturais, sociais, étnicas, econômicas, religiosas, biológicas entre as mulheres; ou, entre homens e mulheres. Elas não têm medo de falar, de perguntar, de se impor. Como feministas, sabem que a luta é diária e estão interconectadas pelas redes sociais, nos coletivos de mulheres e na vida acadêmica.

Cada uma dessas mulheres sinaliza as conquistas e os efeitos gerados pela primeira onda (Maria Alzira); segunda (Maria Alice); e, pela terceira onda feminista (Naiara e Monique). Embora possamos acreditar que esta última onda já esteja caminhando para a quarta, é o período que as jovens mulheres entrevistadas o estão vivenciando. Portanto, é um momento recente e permeado pelo princípio da incerteza, para que possamos categorizá-lo com exatidão.

Em suma, percebemos que as percepções de vida e de mundo estão relacionadas à interpretação que fazemos da realidade, do espírito da época em que vivemos. Cada grupo social possui sua própria narrativa cultural. Assim, neste artigo tivemos o intuito de nos compreendermos melhor e, apreendermos outras ideias complementares à nossas. Desta forma, contribuiu para demonstrar que a nossa percepção é construída social e historicamente; e, a aquisição de novas informações, conhecimentos e de saberes nos fortalece como mulheres, pois amplia a nossa visão de mundo. As constelações e a cosmologia de visões e ângulos diferentes nos permite ampliarmos a nossa percepção para podermos dialogar com outros olhares e saberes.

\section{REFERÊNCIAS}

ADICHIE, Chimamanda Ngozi. Sejamos todos feministas. São Paulo: Cia das Letras, 2014.

ALVAREZ, Sueli e outras. Encontrando os feminismos latino-americanos e caribenhos. Revista Estudos Feministas, Florianópolis, v. 11, n. 2, jul./dez. 2003.

BEARD, Mary. Mulheres e Poder: um manifesto. Espanha: Editora Crítica, 2018.

BEAUVOIR, Simone. O Segundo sexo. Rio de Janeiro: Nova Fronteira, 1980. 
BRASIL. Constituição (1988). Disponível em:

<http://www.planalto.gov.br/ccivil_03/constituicao/constituicao.htm>. Acesso em: 4 jul. 2018.

DAWN. Development alternatives with women for a New Era. Disponível em: <http://dawnnet.org/>. Acesso em: 4 jul. 2018.

DOWLING, Colette. The Cinderella complex: women's hidden fear of independence. Nueva York: Summit Books, 1981.

FRASER, Nancy. Fortunas del Feminismo. Madri: Traficantes de sueños, 2015.

GOULD, Stephen Jay, A Falsa Medida do Homem, 1991.

HALBWACHS, Maurice. A Memória coletiva. São Paulo: Vértice, 1990.

HARAWAY, Donna. Saberes localizados: a questão da ciência para o feminismo e o privilégio da perspectiva parcial. Cadernos Pagu, v. 5, p. 7-41, 1995.

HUNTER, Margaret. The persistent problem of colorism: skin tone, status, and inequality. Sociology Compass, n. 1, p. 237-254, 2007.

LE GOFF, Jacques. História e Memória. Campinas: UNICAMP, 1992.

LUGONES, Maria. Rumo ao Feminismo Decolonial. Revista Estudos Feministas, n.3, v.22, p.1-18, 2014.

MACHADO, Gilka. Crystaes Partidos: poesias. Rio de Janeiro: Revista dos Tribunaes, 1915.

MATOS, Marlise. Movimento e teoria feminista: é possível reconstruir a teoria feminista a partir do sul global? Revistas Sociologia Política, Curitiba, v. 18, n. 36, p. 67-92, jun. 2010.

MCCOMBS, M.; SHAW, D. L. The agenda-setting function of the mass media. Public Opinion Quarterly, n. 36, 1972.

MOUFFE, Chantal. Feminismo, cidadania e política democrática radical: debate Feminista. São Paulo: Cia. Melhoramentos, 1999. Edição Especial. (Cidadania e Feminismo).

ONU (Organização das Nações Unidas). ONU Mulheres Brasil. Disponível em: <http://www.onumulheres.org.br/>. Acesso em: 4 jul. 2018.

PINTO, Céli Regina. Uma História do Feminismo no Brasil. São Paulo: Fundação Perseu Abramo, 2003. 
REED, Evelyn. Is Biology woman's destiny? New York: Pathfinder Press, 1985.

SAFFIOTI, Heleieth I. B. Gênero, Patriarcado, Violência. São Paulo: Fundação Perseu Abramo, 2004.

WHITAKER, Dulce C. A. Envelhecimento e poder: a posição do idoso na contemporaneidade. Campinas: Alínea, 2007. 